\title{
カーボンナノチューブプローブを用いた表面温度計測法*
}

\author{
天野 樹生 ${ }^{* 1}$ ，廣谷 潤 ${ }^{* 2}$, 生田 竜也 ${ }^{* 3}$ ，西山 貴史 ${ }^{* 3, * 4}$, 高橋 厚史 ${ }^{*}, * 5, * 6$
}

\section{Surface Temperature Measurement Using a Carbon Nanotube Probe}

\author{
Juo AMANO ${ }^{*}$, Jun HIROTANI, Tatsuya IKUTA, \\ Takashi NISHIYAMA and Koji TAKAHASHI
}

\author{
${ }^{* 1}$ Department of Aeronautics and Astronautics, Graduate School of Engieering, Kyushu University, \\ 744, Motooka, Nishi-ku, Fukuoka, 819-0395, Japan
}

A new technique of micro/nanoscale temperature measurement is developed using an individual carbon nanotube (CNT) on a platinum hot-film, which can control the heat flow through the CNT probe and sense its own average temperature. A feedback control to extinct the heat flow enables us to neglect the effect of contact thermal resistance and to know the real surface temperature. Spatial resolution of $70 \mathrm{~nm}$, temperature uncertainty of less than $0.5 \mathrm{~K}$ and enough robustness are achieved. Using this method, quantitative temperature profiles are obtained around a line heater of $604 \mathrm{~nm}$-width and $9.73 \mu \mathrm{m}$-length.

Key Words : Quantitative Temperature Measurement, Carbon Nanotube, Pt Hot Film, MEMS

\section{1. 緒言}

近年の電子デバイスの微細化に伴って，マイクロ・ナノデバイスの熱輸送を理解することは機器の信頼性を高 めエネルギを有効に使用するために非常に重要である(1),(2). そのためには信頼のおける定量的温度測定手法が必 要不可欠であり，これまでにマイクロ・ナノスケールの温度分布を測定する様々な実験的手法が開発されてきて いる．非接触型の測定手法としては，放射赤外光の強度あるいはレーザの反射率変化を用いた計測があるが，そ れらの空間分解能は光の波長程度に限定される。近年では物質表面近傍に存在する近接場光を用いて温度分布を 測定する熱顕微鏡(3),(4)が提案され，光の波長をはるかに下回るナノオーダーの高い空間分解能を有することが示 されている．しかしながら非接触の計測手法では，試料表面の光学特性と温度の関係を正確に把握する必要があ る. そのため，未知の試料に対しては事前のキャリブレーションや光学特性が既知の試料を用いて表面コーティ ングするなどの改善が必要となる。接触型の温度計測手法としては, 測温抵抗型や熱電対などの温度センサが使 用されている。これまでにウォーラストンワイヤを用いた測温抵抗器 ${ }^{(5)}{ }^{(7)}$ あいは熱電対を原子間力顕微鏡

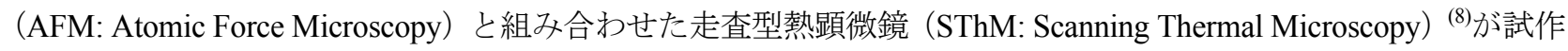
研究されている. SThM は AFM としての機能も有するため試料の表面形状と温度分布の両方を測定することが でき，近年では MEMS 技術に基づいて AFM のカンチレバーの探針に Pt と Cr の薄膜を蒸着することで熱電対の 機能を付加して SThM の性能を向上させようとする試みもされている(9),(10). 光学式と比べてキャリブレーション を行う必要性が少なく空間分解能は接点の大きさで制御できるのが利点である.

\footnotetext{
* 原稿受付 2012 年 10 月 30 日

*1 九州大学 大学院 工学府 航空宇宙工学専攻

*2 正員, 九州大学 大学院 工学府 航空宇宙工学専攻

*3 九州大学 大学院 工学研究院 航空宇宙工学部門

*4 (独) 科学技術振興機構 戦略的創造研究推進事業

*5 正員, 九州大学 大学院 工学研究院 航空宇宙工学部門 (下819-0395 福岡県福岡市西区元岡 744 番)

*6 九州大学カーボンニュートラル・エネルギー国際研究所

E-mail: takahashi@aero.kyushu-u.ac.jp
} 
しかしながら，試料の温度を接触型で正確に測定するには接触熱抵抗の問題が立ちはだかる．接触熱抵抗はそ のメカニズムが未解明な上に状況次第で大きく変わることが知られている. 例えば, 従来型の SThM では Si 系材 料を用いているが，接触熱抵抗を低く抑えるためには探針を強く押しつける必要があり走査時間の増加とともに 探針先端が摩耗して接触状態が変化する. 加えて, 試料表面に存在する液体メニスカスや空気を通る熱伝導によ って定量的な局所温度分布測定は難しい(9). 最近では, 試料表面の液体メニスカスや空気への伝熱の影響を排除 するために Kim らによる超高真空下での計測例が報告(11)されているが, そこで採用されている接触熱抵抗の較正 は計測時間と手間を増加させることから実用的とは言い難い。一方, Nakabeppu らはカンチレバーに伝わる熱量 をカンチレバー表面に作りこんだ熱電対を用いて測定し, その情報を用いてヒータの加熱量を制御することでカ ンチレバーの温度と測定対象の試料温度を一致させるフィードバック式の温度計測手法を提案している(12). この 手法においては，測定対象の表面温度とカンチレバーの温度が一致したとき，探針から試料へ流れる（あるいは 探針一流れてくる）熱流が発生しないため, 探針と試料表面の接触熱抵抗に依存しない定量的温度計測が可能と なる。そこで我々は Nakabeppu らの手法を原理的に採用するとともに，従来の Si 系材料よりも摩耗に強くかつ 鋭利な材料であるカーボンナノチューブ（CNT: Carbon Nanotube） ${ }^{(13)}$ を探針として使用することで高い空間分解 能を長期間維持し得る表面温度計測法を開発することとした.

$\mathrm{CNT}$ はハニカム構造の $\mathrm{sp}^{2}$ 混成軌道ネットワークが巻き取られることでつなぎ目のない円筒を形成したもので, 直径がナノメートルオーダーで高い強度とアスペクト比を有することから，AFM の探針材料として有望と考え られている。これまでに CNT を用いた AFM 測定によって著しい空間分解能の改善を成し遂げた報告もある(14). 単層カーボンナノチューブ（SWCNT: Single Walled Carbon Nanotube）を利用すれば理論上 $1 \mathrm{~nm}$ 程度までの空間 分解能を実現できるが，SThM など熱測定のためのデバイスは多層単層問わず未だに実現していない，我々はこ れまでMEMS 技術で作製した白金ホットフィルムに一本のCNT を装着したデバイスを用いて, CNT 先端と固体 表面の間の接触熱抵抗の問題 ${ }^{(15)}$ を定量的に研究してきた。 その手法は一本の CNT の熱伝導率測定手法 ${ }^{(16)}$ を拡張 したものである．本論文では，そのデバイスを用いた表面温度の定量的測定原理を説明するとともに，手法の妥 当性を示すために行った実験について報告する.

\section{2. 温 度 計 測 手 法}

\section{$2 \cdot 1$ 計測原理}

温度計測の伝熱モデルを図 1 に示す。ここで $k ， A ， L$ はそれぞれ熱伝導率，断面積，長さである．なお添字の $h$ と $p$ はそれぞれ白金ホットフィルムと CNT プローブを表す. $x_{i}(i=1-3)$ は座標であり， $T_{0}$ はホットフィルムの両 端の電極を兼ねる熱浴の温度である. ホットフィルム及び CNT のアスペクト比は十分に大きく一次元熱伝導方 程式で記述できる．計測は真空中（10 $\left.0^{-3} \mathrm{~Pa}\right)$ で行うため熱伝達は無視できる．また，白金ホットフィルムの最大 温度上昇量はせいぜい $20 \mathrm{~K}$ 程度であるため, このときの輻射による熱損失は発熱量全体の $1 \%$ 未満となる．この ため輻射熱損失も無視できる．よって白金ホットフィルム部分の熱伝導方程式は式（1）のように表せる.

$$
k_{h} \frac{\partial^{2} T_{i}\left(x_{i}\right)}{\partial x_{i}^{2}}+q_{h}=0 \quad \text { for } i=1,2
$$

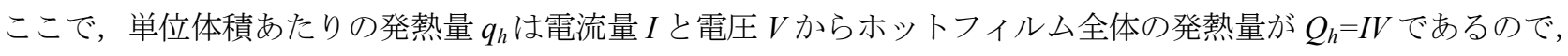

$$
q_{h}=\frac{Q_{h}}{A_{h}\left(L_{1}+L_{2}\right)}
$$

また CNT 部分は Joule 発熱がないため, 熱伝導方程式は次式のようになる.

$$
k_{p} \frac{\partial^{2} T_{3}\left(x_{3}\right)}{\partial x_{3}^{2}}=0
$$

式（1），(3）を解いて式（2）を代入することで, 次の式（4）～（6）の一般解を得る. 


$$
\begin{aligned}
& T_{1}\left(x_{1}\right)=-\frac{Q_{h}}{2 k_{h} A_{h}\left(L_{1}+L_{2}\right)} x_{1}^{2}+C_{1} x_{1}+C_{2} \\
& T_{2}\left(x_{2}\right)=-\frac{Q_{h}}{2 k_{h} A_{h}\left(L_{1}+L_{2}\right)} x_{2}{ }^{2}+C_{3} x_{2}+C_{4} \\
& T_{3}\left(x_{3}\right)=C_{5} x_{3}+C_{6}
\end{aligned}
$$

ここで， $\mathrm{C}_{1}$ から $\mathrm{C}_{6}$ は積分定数である. CNT 先端が試料表面に接触していない場合には，境界条件として式（7） のホットフィルム両端の温度のみを考えればよい。

$$
T_{i}(0)=T_{i}\left(L_{1}+L_{2}\right)=T_{0} \quad \text { for } i=1,2
$$

よって，式（4）または（5）と式（7）より白金ホットフィルムの温度分布は次のように求まる。

$$
T_{1}\left(x_{1}\right)=-\frac{Q_{h}}{2 k_{h} A_{h}\left(L_{1}+L_{2}\right)} x_{1}^{2}+\frac{Q_{h}}{2 k_{h} A_{h}} x_{1}+T_{0}
$$

$T_{2}\left(x_{2}\right)$ も式（8）と同様に表現できる.ここで CNT と白金ホットフィルムの接合点温度 $T_{j}$ は $x_{1}$ （あるいは $x_{2} ）$ に $L_{I}\left(L_{2}\right)$ を代入することで求めることができる.

$$
T_{j}=T_{1}\left(L_{1}\right)=T_{2}\left(L_{2}\right)=\frac{Q_{h}}{2 k_{h} A_{h}} \frac{L_{1} L_{2}}{L_{1}+L_{2}}+T_{0}
$$

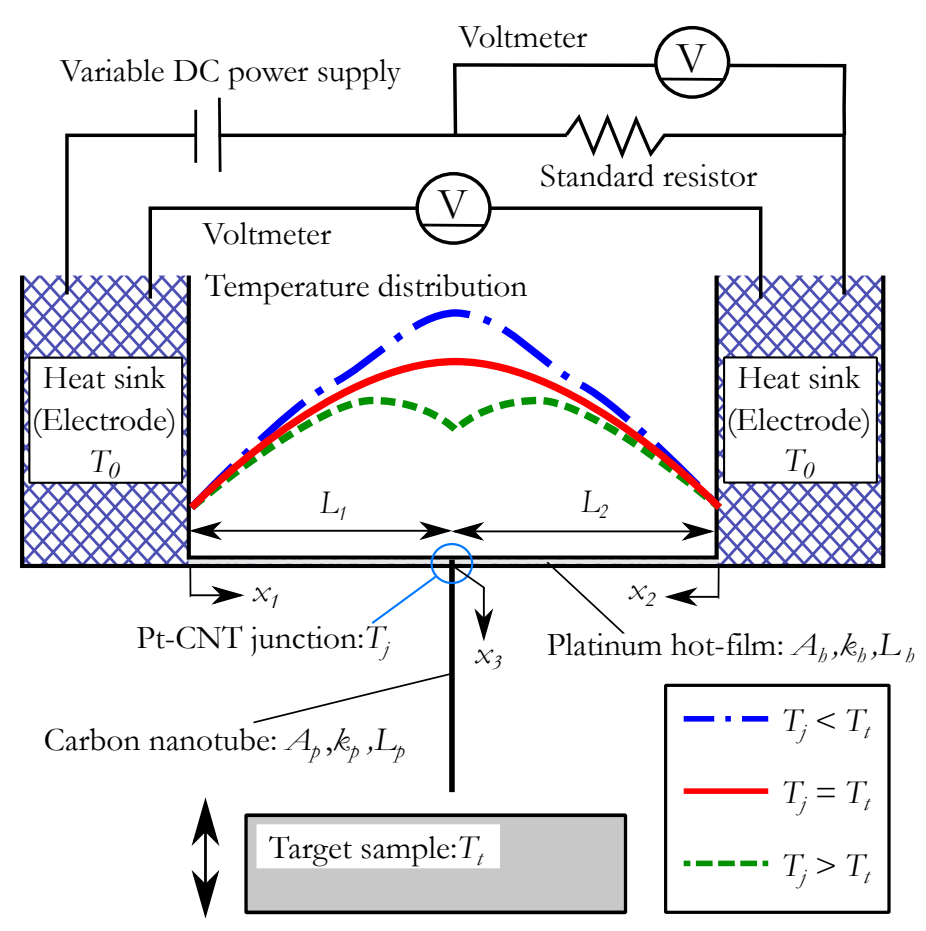

Fig.1 Heat transfer model of a suspended platinum nano hot-film with an individual carbon nanotube probe. $T_{j}$ and $T_{t}$ are the hot-film temperatures at the CNT-Pt junction and target sample surface temperature, respectively. The temperature distributions along the Pt film for three cases are shown: CNT-Pt junction temperature, $T_{j}$, is same as the sample surface temperature, $T_{t}$, or higher, or lower than $T_{t}$. 
次にCNT 先端が試料表面に接触した場合を考える。このとき境界条件は式（10）から（15）で表される.

$$
\begin{aligned}
& T_{1}(0)=T_{0} \\
& T_{2}(0)=T_{0} \\
& T_{1}\left(L_{1}\right)=T_{2}\left(L_{2}\right) \\
& -k_{h} A_{h}\left[\left.\frac{\partial T_{1}\left(x_{1}\right)}{\partial x_{1}}\right|_{x_{1}=L_{1}}+\left.\frac{\partial T_{2}\left(x_{2}\right)}{\partial x_{2}}\right|_{x_{2}=L_{2}}\right]=-\left.k_{p} A_{p} \frac{\partial T_{3}\left(x_{3}\right)}{\partial x_{3}}\right|_{x_{3}=L_{p}} \\
& -\left.k_{p} A_{p} \frac{\partial T_{3}\left(x_{3}\right)}{\partial x_{3}}\right|_{x_{3}=0}=\frac{T_{1}\left(L_{1}\right)-T_{3}(0)}{R_{h-p}} \\
& -\left.k_{p} A_{p} \frac{\partial T_{3}\left(x_{3}\right)}{\partial x_{3}}\right|_{x_{3}=L_{p}}=\frac{T_{3}\left(L_{p}\right)-T_{t}}{R_{p-t}}
\end{aligned}
$$

ここで， $T_{t}$ は試料表面の温度であり， $R_{h-p}$ と $R_{p-t}$ はそれぞれ白金ホットフィルムと CNT, CNT と試料表面間の 接触熱抵抗である. 式（4）から（6）を境界条件式（10）から（15）のもとで解くことで，ホットフィルム及び $\mathrm{CNT}$ 部分の温度分布を得ることができる．得られる温度分布は CNT プローブの熱抵抗 $R_{p}=L_{p} / k_{p} A_{p}$ と 2 つ接触 熱抵抗 $R_{h-p}$ と $R_{p-t}$ の 3 つの熱抵抗の和に影響を受ける. 熱浴温度 $T_{0}$ と同じ場合の詳しい表現は参考文献 ${ }^{(15)}$ にある. CNT を伝わる熱量と 3 つの熱抵抗和が求まれば，試料表面温度を求めることができる．しかしながら CNT の熱 伝導率は使用寸る CNT ごとに異なるため, CNT 自体の熱抵抗にも誤差が含まれる. また 2 つの接触熱抵抗 $R_{h-p}$ や $R_{p-t}$ も接触状態によって值が異なるため厳密に推定するのは困難である. そのためホットフィルム - 試料間に CNT を通して熱の移動がある場合, 試料温度 $T_{t}$ を正確に求めることは難しい.

そこで, CNT プローブの試料表面への接触前後で温度分布が変化しない状況を作ることを考える. ここで CNT が試料表面に接触した場合の熱の移動に着目する. CNT-白金ホットフィルムの接合点の温度より試料表面の温度 が低い場合，白金ホットフィルム中の熱の一部が CNT を通して試料へ流れる。このため，温度が低下し温度分 布は図 1 中の破線のようになる. 反対に CNT-白金ホットフィルムの接合点の温度よりも試料表面の温度が高い 場合, CNT を通して白金ホットフィルムへ熱が流入し，ホットフィルムの温度分布は図 1 中の一点鎖線のように なる．さらに，CNT-白金ホットフィルムの接合点の温度が試料表面と同じ温度である場合は，CNT を通る熱の 移動はないため, 非接触時の温度分布のまま変化はない. 図 1 に示すように白金フィルム中の発熱量は電流量を 調節することによって制御でき, 非接触時と接触時で温度変化がなくなるようにすることで, 試料表面と CNT白金ホットフィルム接合点の温度を同じにすることができる．このとき試料表面の温度を CNT-白金ホットフィ ルム接合点の温度として定量的に推定することができる.

ホットフィルムと CNT の接合点の温度は式（9）から算出できる.この式（9）ではホットフィルムの熱伝導 率を代入する必要があるが, ホットフィルムには温度分布があるため, 局所的には熱伝導率は異なる. そこで木 ットフィルム全体の平均温度 $T_{a v e}$ と校正によって得られる熱伝導率と温度の関係から平均熱伝導率 $k_{h}$ を算出し式 （9）での計算に使用する．白金は広い温度域に対して，温度と電気抵抗が線形の関係があるため，白金ホットフ イルムの電気抵抗 $R_{h}$ は平均温度 $T_{\text {ave }}$ との関係式 $T_{a v e}=\left(R_{h}-R_{r e f}\right) / \alpha+T_{r e f}$ から決定できる. このとき $\alpha$ は校正試験 によって得られた白金の温度抵抗係数であり， $R_{\text {ref }}$ は基準電気抵抗， $T_{\text {ref }}$ は基準温度である. 本研究では基準温度 を $T_{r e f}=300 \mathrm{~K}$ とし，このときの電気抵抗を基準電気抵抗 $R_{r e f}$ とする. 計測した電気抵抗からホットフィルムの平 均温度を求め, 事前に較正した温度と熱伝導率の関係を用いてホットフィルムの熱伝導率を推算する. 
図 2 は実験で使用したセンサの SEM 画像である. 白金ホットフィルムが $\mathrm{SiO}_{2} / \mathrm{Si}$ 基板の端に作製され，CNT の 片端がホットフィルムに接合されているのがわかる。もう一方の CNT の端は基板の端から飛び出した構造とな っており，CNT 先端を任意の試料表面に接触させることができるようになっている.

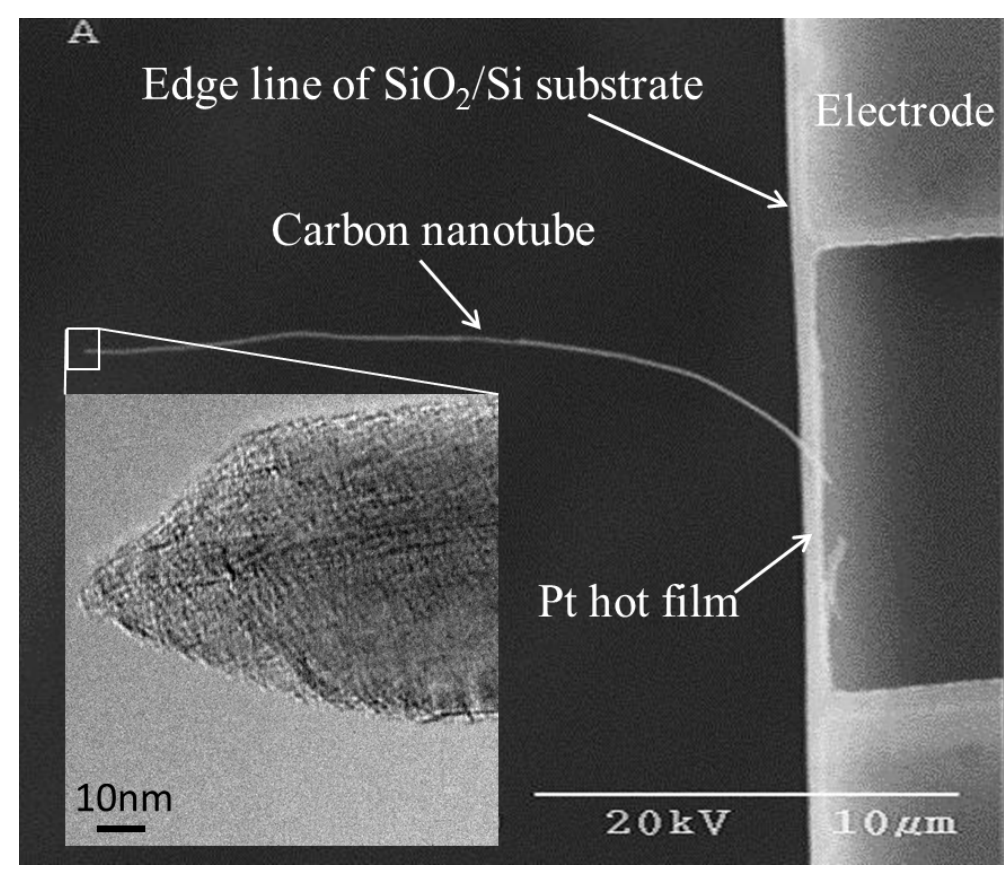

Fig. 2 SEM image of the fabricated sensor. The CNT is fixed on the Pt hot film and protrudes from the silicon substrate. Two Pt electrodes work as heat sinks. Inset: HRTEM image of the CNT end.

\section{$2 \cdot 2$ 計測手順}

CNT 先端が試料に接触していない状態で, ホットフィルムに電流を流し, Joule 加熱によって生じた電圧值 $V_{\text {before }}$ を測定する, その後, CNT 先端を試料表面に接触させ, 接触後のホットフィルム部の電圧值 $V_{\text {after }}$ を測定する. こ の接触後の電圧が接触前よりも増加/減少した場合は, 加熱している電流 $I$ を増加/減少させる. このフィードバッ クを接触前後の電圧值 $V_{\text {before }}$ と $V_{\text {after }}$ が温度制御の不安定性から生じる電圧の摇動以内に収まるまで繰り返す。こ のとき，接触前後の電圧值が一致したと見なす．そして，一致したときの電圧 $V_{\text {before }}\left(\right.$ あるいは $V_{\text {affer }}$ ）とそのと きの加熱電流 $I$ を用いてホットフィルム部の電気抵抗 $R_{h}$ をオームの法則から算出する. この電気抵抗 $R_{h}$ からホ ットフィルムの平均熱伝導率 $k_{h}$ を求め，ホットフィルム全体の加熱量 $Q_{h}$ とともに式(9)に代入することで，ホッ トフィルムと CNT 接合部（試料表面）の温度 $T_{j}$ を計算する. 最後に試料表面温度 $T_{t}$ は $T_{t}=T_{j}$ であるので，任意の 表面温度を定量的に求めることができる。
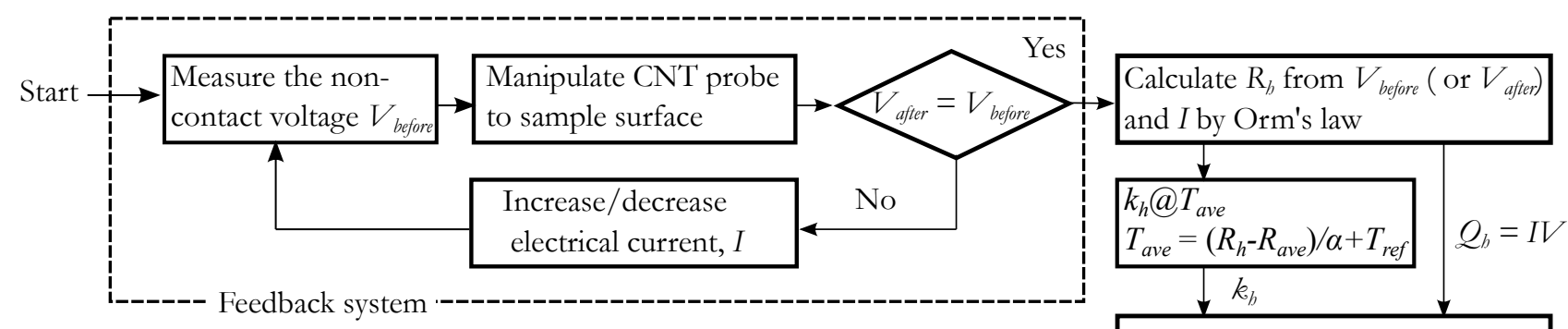

$T_{t}$ is estimated by equation (9)

Fig. 3 Flow chart of the experimental procedure. $V_{\text {before }}$ and $V_{\text {after }}$ represent the voltage of the Pt hot film in CNT non-contact and contact modes, respectively. Electrical current $I$ changes the heat generation to meet the $V_{\text {before }}=V_{\text {after }}$. When $V_{\text {before }}=V_{\text {affer }}, T_{t}=T_{j}$. 


\section{3. 実 験 結 果}

\section{$3 \cdot 1$ 温度計測手法の有効性検証}

開発した CNT プローブセンサによる定量的温度計測手法は, 今後 AFM との複合や自動制御化を進めることで 工業的に有用なシステムになることが期待できるが，まずは第一段階として本計測原理の有効性を検証する必要 がある．そこで温度が既知の試料に対する温度測定を行った．図 4 に検証実験の概要を示す．試験は SEM 中で 行い，センサチップ全体はペルチェ素子による温度制御ステージに固定され一定温度に保たれている．温度が既 知の試料として銅ブロックを用意し，測定箇所と同じ高さで測定面から $3 \mathrm{~mm}$ 内側に側面から梁さ $6 \mathrm{~mm}$ の穴を あけグリースによって温度計を埋め込む. 銅ブロックの温度はヒータ上に固定され温度を変化させることができ, ヒータ下部には断熱材が取り付けてある. CNT 先端と試料間の相対的位置関係はナノマニピュレータ (Kleindiek MM3A-EM）を用いて制御することで，CNT プローブの非接触及び接触状態を実現する．この銅ブロックに取り 付けられた温度計の示す温度と, 開発した温度計測手法を用いた測定結果を比較することで有効性を検証する.

検証実験によって得られた温度計の温度と CNT プローブセンサにより測定された温度を表 1 に示す．表 1 に おいて温度計の誤差として示される温度の不確かさは校正の基準とした白金測温抵抗体の標準誤差から生じるも のである. また, CNT プローブセンサの誤差は電圧の読みから推定される温度の誤差を示している. ペルチェに よりセンサは一定温度（301.4 K）に保たれており，ヒータを用いた銅の加熱によって，センサ側と銅ブロック間 で温度差が生じるが, $10 \mathrm{~K}$ 以下であるため輻射の影響は無視できる. 測定された温度と温度計の值を比較すると それぞれの温度での測定の不確かさを除いて $0.5 \mathrm{~K}$ 以内, 不確かさを含めた場合でも $1 \mathrm{~K}$ 以内の誤差となり, 今 回検証した温度範囲（304.6 311.8 K）において開発した定量的温度計測手法の有効性を確認することができた. しかしながらさらに広い温度範囲での検証や, AFM との統合システム化後の計測制度を検討することは今後の課 題である.

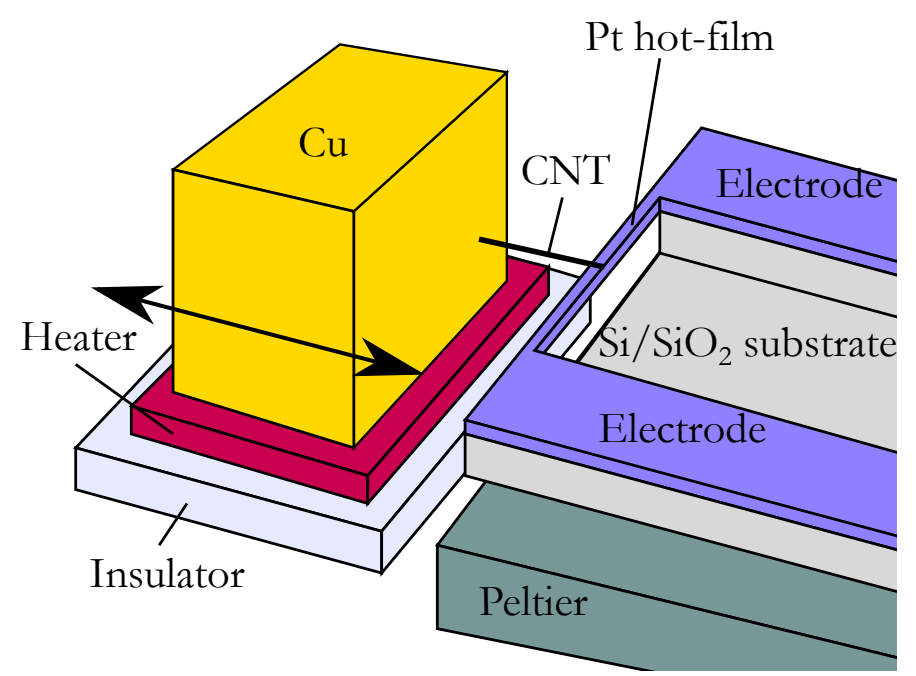

Fig. 4 Schematic of the measurement test for temperature-known $\mathrm{Cu}$ surface

Table 1 Comparison of temperatures obtained from the thermometer and from our measured data at the sample surface.

\begin{tabular}{cc}
\hline \hline $\begin{array}{c}\text { Thermometer } \\
{[\mathrm{K}]}\end{array}$ & $\begin{array}{c}\text { Estimated temperature } \\
{[\mathrm{K}]}\end{array}$ \\
\hline $311.8 \pm 0.23$ & $311.3 \pm 0.3$ \\
$309.7 \pm 0.22$ & $309.4 \pm 0.3$ \\
$307.7 \pm 0.22$ & $308.1 \pm 0.3$ \\
$305.7 \pm 0.22$ & $306.0 \pm 0.3$ \\
$304.6 \pm 0.21$ & $304.6 \pm 0.3$ \\
\hline \hline
\end{tabular}




\section{$3 \cdot 2$ 温度分布計測例}

図 5(a)に示す通電加熱したラインヒータを測定対象として表面温度計測を行った. ラインヒータは $\mathrm{Si}$ 基板上の 膜厚約 $200 \mathrm{~nm}$ の $\mathrm{SiO}_{2}$ 上に $\mathrm{Ti}(8 \mathrm{~nm}), \mathrm{Pt}(42 \mathrm{~nm})$ を堆積させライン状にパターニングすることで基板の端にラ インヒータを作製する。作製されたラインヒータは長さ $9.73 \mu \mathrm{m}$ ，幅 $604 \mathrm{~nm}$ 及び高さ $49.9 \mathrm{~nm}$ である.このライ ンヒータに $1.5 \mathrm{~mA}$ と $3.0 \mathrm{~mA}$ の定電流を与えることで発熱させ，二通りの条件で実験を行った. 実験は SEM 中 で行い，温度計測は図 3 と同じ手順で測定する。マニピュレータを用いてセンサとラインヒータの位置関係を調 節することで，接触/非接触状態の実現した。代表的な測定点の SEM 画像を図 5(b)に示す. 温度測定は図 5(b)の 矢印で示すように二通り行った。一つはラインヒータの上面を中心から離れるようにともう一つは基板上をライ ンヒータから離れる方向へ測定する. 実験時の接触/非接触の判定は SEM 画像から判断する. CNT 先端は試料表 面間と van del Waals 力によって接触しており，接触した状態で CNT 試料表面に押し付けていくと接触点の位 置は変わらずにCNT が曲がる。このとき CNT 先端が試料表面に接触していると判断することができる
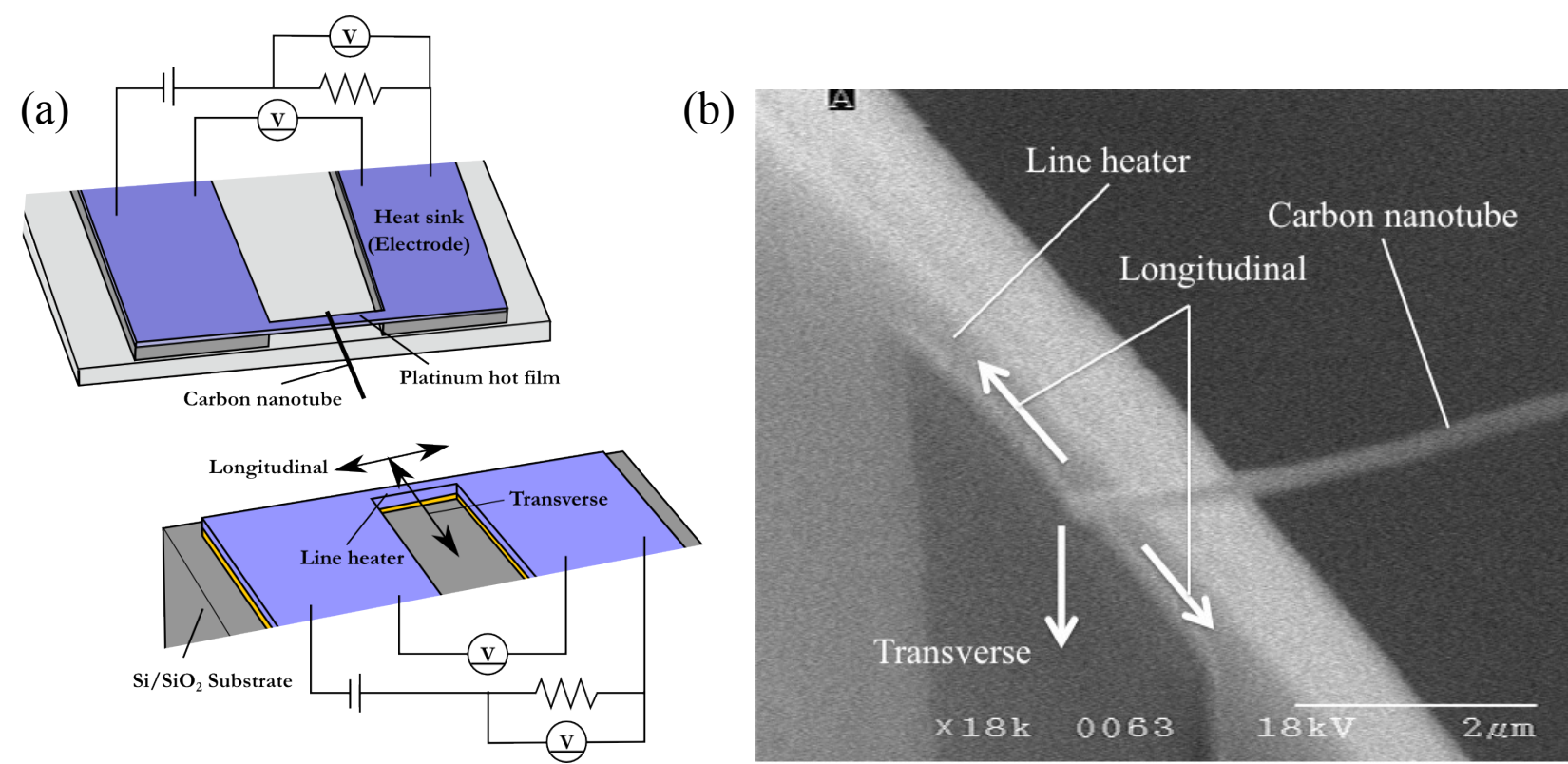

Fig. 5 (a) Schematic diagram of a temperature measurement using a carbon nanotube probe. The sample is a line-patterned Pt/Ti film, and line patterned heater is connected to electrodes. (b) Tilted SEM image during measurement. The coordinates are defined as along the line heater (longitudinal direction) and perpendicular to the line heater (transverse direction).
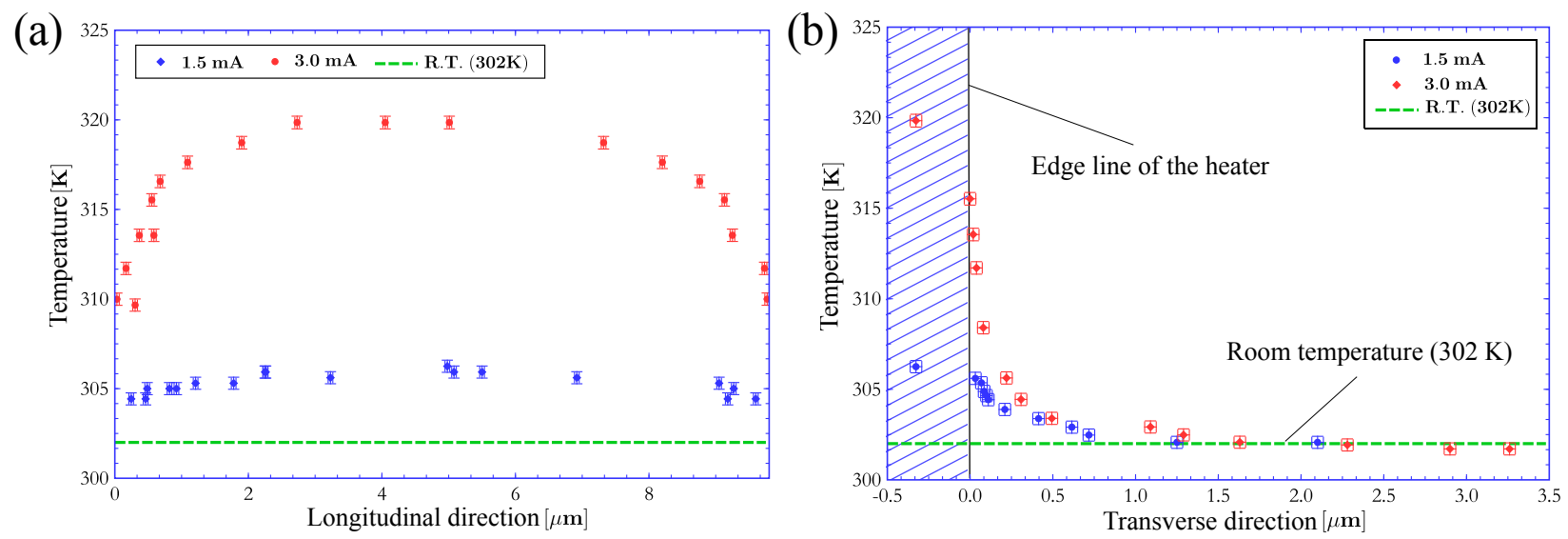

Fig. 6 (a) Temperature measurements along the Pt heater (longitudinal direction) for the $3.0 \mathrm{~mA}$ and $1.5 \mathrm{~mA}$ heating cases. Dashed line is room temperature in the experiment as $302 \mathrm{~K}$. (b) Target surface temperature distributions perpendicular to the Pt heater (transverse direction). The origin is the edge of the $\mathrm{Pt} / \mathrm{Ti}$ heater. Measured temperatures are the same as the room temperature at about $1.5 \mu \mathrm{m}$ distance away from the heater. 
なお CNT プローブを動かすマニピュレータ（Kleindiek MM3A-EM）の空間解像度は $5 \mathrm{~nm}$ 以下であるが，CNT は柔軟であるためマニュピレータの位置情報だけでは大きな誤差を生む.このため, CNT を接触させたポイン トごとに SEM 画像から接触位置を判定している.

まず，ラインヒータの長手方向に沿った方向（Longitudinal）の温度分布を図 6(a)に示す．グラフの横軸の両端 がラインヒータの端部である. 図 6 中の丸印が $3.0 \mathrm{~mA}$, 四角印が $1.5 \mathrm{~mA}$ の電流を与えた場合の結果である. 図 6(a)で見られるデータのばらつきは，幅 $600 \mathrm{~nm}$ 程度の極細ヒータ上に存在する製造工程上不可避なバリ（線幅両 サイドの突起）の影響が考えられる。このバリは基板に接していないため基板と接している部分に比べ温度が若 干高くなっており，そこに CNT プローブが触れることでスキャン中に若干の温度の乱れが生じる. 横軸の位置 計測誤差は CNT の直径 $(70 \mathrm{~nm})$ による読み取り誤差である. ラインヒータ両端の温度が室温と一致していない 理由は今回用いたラインヒータ基板が温度制御されておらず大電流による Joule 発熱によってヒータ端部の基板 温度が上昇していることを意味する. 次にラインヒータに直行する方向（Transverse）への測定結果を図 6(b)に示 寸.横軸はヒータからの距離であり縦軸が測定温度である. 斜線部分はラインヒータ上であることを表している. ラインヒータから離れるにつれて温度が下がり $1.5 \mu \mathrm{m}$ 程度離れた位置では測定温度は室温 $(302 \mathrm{~K})$ に一致した. 長手方向では二次関数的な, 直交する方向では指数関数的なプロファイルを示す.これは理論と整合するもので 本研究の有効性が確認された.

\section{4. 結言}

CNT をプローブとして使用したマイクロ・ナノスケールの表面温度計測法を開発した. CNT 中を通る熱流がゼ ロとなるようフィードバック制御を行い, 測定対象とホットフィルムの温度を一致させる. これにより CNT 先 端と試料表面間の接触熱抵抗の影響を排除した定量的温度測定が可能になる.また, CNT が高強度かつ化学的に 安定であるため, 本センサは非常に高いロバスト性を有し, CNT 直径である $70 \mathrm{~nm}$ 程度の空間分解能を実現した. 予備試験の結果から温度の不確かさを除いて誤差 $0.5 \mathrm{~K}$ であることを確認し, 表面温度測定に有効であることを 証明した. さらに, 基板の端に作製した Pt 薄膜のラインヒータの長手方向とそれに直交する方向の二方向の温度 を測定し, ヒータ上およびヒータ近傍の温度分布を捉えることができた. 本研究で開発した定量的温度計測手法 は，さらなるナノスケールの熱輸送現象の解明に役立つものと期待できる.

\section{謝 辞}

本研究におけるセンサの作製には, 九州大学 Collabo-Station II の電子線描画装置を利用しました．また，本研 究の一部は JSPS 科学研究費補助金 23360101，23656153，23760191，24560237 の助成を受けたものです.また, CNT の観察には九州大学超高圧電子顕微鏡室を利用しました。ここに謝意を表します.

\section{文献}

(1) Cahill D. G., Ford, W. K., Goodson, K. E., Mahan, G. D., Majumdar, A., Maris, H. J., Merlin, R., Philpot, S. R., “Nanoscale thermal transport", Applied Physics Letter, Vol. 93, No. 2 (2003), pp. 793-818.

(2) Pop, E., "Energy dissipation and transport in nanoscale device", Nano Research, Vol. 3, No. 3 (2010), pp. 147-169.

(3) Goodson, K. E., and Asheghi, M., "Near-field optical thermometry", Microscale Thermophysical Engineering, Vol. 1 No. 3 (1997), pp. 225-235.

(4) Taguchi, Y., Oka, T., Saiki, T., and Nagasaka, Y., "Development of near-field fluorescence lifetime thermometry", Nanoscale and Microscale Thermophysical Engineering, Vol. 13, No. 2 (2009), pp. 77-87.

(5) Sano, M., Yudasaka, M., Kikuchi, R., and Yoshimura, S., "Anomalous resolutions in scanning thermal microscopy of graphite", Langmuir, Vol. 13, No. 17 (1997), pp. 4493-4497.

(6) Volz, S., Feng, X., Fuentes, C., Guérin, P., and Jaouen, M., "Thermal conductivity measurements of thin amorphous silicon films by scanning thermal microscopy”, International Journal of Thermophysics, Vol. 23, No. 6 (2002), pp. 1645-1657. 
(7) Lefe' vere, S., Volz, S., and Chapuis, P.-O., "Nanoscale heat transfer at contact between a hot tip and substrate", International Journal of Heat and Mass Transfer, Vol. 49, No. 1-2 (2006), pp. 251-258.

(8) Majumdar, A., Carrejo, J. P., and Lai, J., "Thermal imaging using the atomic force microscope”, Applied Physics Letters, Vol. 62, No. 20 (1993), pp. 2501-2503.

(9) Shi, L., Plyasunov, S., Bachtold, A., McEuen, P., and Majumdar, A., "Scanning thermal microscopy of carbon nanotubes using batch-fabricated probes", Applied Physics Letters, Vol. 77, No. 26 (2000), pp. 4295-4297.

(10) Shi, L., and Majumdar, A., "Thermal transport mechanisms at nanoscale point contacts", Journal of Heat Transfer, Vol. 124, No. 2 (2002), pp. 329-337.

(11) Kim, K., Jeong, W., Lee, W., and Reddy, P., "Ultra-high vacuum scanning thermal microscopy for nanometer resolution quantitative thermometry", ACS Nano, Vol. 6, No. 5 (2012), pp. 4248-4257.

(12) Nakabeppu O., and Suzuki, T., "Microscale temperature measurement by scanning thermal microscopy", Journal of Thermal Analysis and Calorimetry, Vol. 69, No. 3 (2002), pp. 727-737.

(13) Iijima, S., "Helical Microtubules of Graphitic Carbon", Nature, Vol. 354, (1991), pp. 56-58

(14) Wilson, N. R., and Macpherson, J. V., "Carbon nanotube tips for atomic force microscopy”, Nature nanotechnology, Vol. 4, (2009), pp. 483-491.

(15) Hirotani, J., Ikuta, T., and Takahashi, K., "Experimental study on thermal contact resistance at the end of a carbon nanotube", International Journal of Thermophysics, DOI:10.1007/s10765-011-1137-1.

(16) Fujii, M., Zhang, X., Xie, H., Ago, H., Takahashi, K., Ikuta, T., Abe, H., and Shimizu, T., "Measuring the thermal conductivity of a single carbon nanotube", Physical. Review Letters, Vol. 95, No. 6 (2005), pp. 065502. 